\title{
Expression of integrins, cyclooxygenases and matrix metalloproteinases in three-dimensional human endometrial cell culture system
}

\author{
Hyunwon Yang ${ }^{1}$, Sungwon Han², Haekwon Kim³, \\ Young Min $\mathrm{Choi}^{4}$, Kyung Joo Hwang ${ }^{5}$, \\ Hyuck Chan Kwon ${ }^{6,8}$, Sei Kwang Kim ${ }^{7}$ and \\ Dong Jae Cho ${ }^{7}$ \\ ${ }^{1}$ Cardiovascular Research Institute, Brain Korea 21 Project for Med- \\ ical Science, Yonsei University College of Medicine, Seoul, \\ ${ }^{2}$ Medical Science Institute, Eulji Medical Center, Seoul, \\ ${ }^{3}$ Department of Biotechnology, Seoul Women's University, Seoul, \\ ${ }^{4}$ Department of Obstetrics and Gynecology, Seoul National Univer- \\ sity College of Medicine, Seoul, \\ ${ }^{5}$ Department of Obstetrics and Gynecology, Ajou University School \\ of Medicine, Suwon, \\ ${ }^{6}$ Department of Obstetrics and Gynecology, Eulji University School \\ of Medicine, Seoul, \\ ${ }^{7}$ Department of Obstetrics and Gynecology, Yonsei University Col- \\ lege of of Medicine, Seoul, Korea \\ ${ }^{8}$ Corresponding author: Tel, +82-2-970-8230; \\ Fax, +82-2-970-8231; E-mail, khc3114@eulji.or.kr
}

Accepted 4 March 2002

Abbreviations: COX, cyclooxygenase; ECM, extracellular matrix; $E E$, endometrial epitherial; $E S$, endometrial stromal; MMP, matrix metalloproteinase; TIMP, tissue inhibitor of metalloproteinase

\begin{abstract}
The objective of this investigation was to establish a three-dimensionally cultured human endometrium which could be used as a tissue model for the mechanism study of implantation in vitro. By using human endometrial stromal (ES) and epithelial cells (EE) from hysterectomy specimens, reconstruction of endometrium in culture was established by first layering a collagen gel containing ES cells, then overlaying with the Matrigel containing endometrial epithelial (EE) cells. Ultrastructural examination of the $48 \mathrm{~h}$-endometrial cell culture revealed monolayered columnar EE cells with microvilli on the collagen layer containing ES cells and appearance of the tight junctions and desmosomes between EE cells, a cell layer closely resembling the native endometrium. Immunohistochemical characterization of the reconstructed endometrium showed a strong immunoreactivity for cytokeratin, integrin $\alpha 1, \alpha 4$ and
\end{abstract}

$\beta 3$ subunits, cyclooxygenases -1 and -2 , matrix metalloproteinases-1, $-2,-3$ and -9 , and tissue inhibitor of metalloproteinases- 1 and -2 in the EE cells comparable to the native endometrial epithelium. ES cells also showed stronger immunoreactivity for cyclooxygenases, integrins and MMPs, but less for cytokeratin. Gelatin zymographic analyses of the media obtained from the reconstructed endometrium model showed gelatinase activity bands at 57, 60, 72, 92 and $97 \mathrm{kDa}$ molecular weight, respectively. The present study provides a possibility that our threedimensionally cultured endometrium model could mimic the morphological and functional characteristics of the native endometrium. The model could be used to clarify the roles of various molecules involved in the human implantation.

Keywords: cyclooxygenase, endometrium, integrin, metalloproteinase, three-dimensional cell culture

\section{Introduction}

The human endometrial cycle, which can be divided into proliferative, secretory and menstrual phases, is characterized by the alteration of cycle-specific morphology and function. In addition to sex steroid hormones known to be primary regulators of the endometrium cycle, many other substances including cytokines and adhesion molecules have been suggested to play important roles in the cyclic change of endometrium (Tabibzadeh and Sun, 1992; Charnock-Jones et al., 1994; Giudice, 1994; Fowle et al., 2000; Salamonsen et al., 2000). Further, cycle dependent expression of integrins, matrix metalloproteinases (MMPs) and cyclooxygenases (COXs) may provide specific markers for evaluating endometrial receptivity at the time of implantation. (Hulboy and Martrisian, 1997; Jones et al., 1997; Kwon et al., 1999; Acosta et al., 2000). The use of biopsied endometrial tissues in culture allowed some investigation of differentiation mechanism of the human endometrium during implantation window. Also, in vitro studies using monolayer culture of endometrial stromal (ES) and/or epithelial (EE) cells have also been tried to characterize molecules expressed in these cells relating to implantation. ES or EE cells grown in monolayer culture system failed to differentiate into columnar cells found in the endometrium (Hearn, 1986) and the information obtained 
from those monolayer cultures does not reflect the in vivo endometrium. (Sillem et al., 1997; Simon et al., 1997). The interaction between the endometrial compartments, i.e., ES and EE cells and extracellular matrix (ECM), is known to be an important factor for the endometrium differentiation (Osteen et al., 1994). In an attempt to overcome the pitfalls of the monolayer culture system, Bentin-Ley et al. (1994) have developed a three-dimensional culture system of the EE and ES cells using collagen gel and Matrigel. Ultrastructural studies and anti-cytokeratin and -collagen antibodies, reactivity of the cell culture system showed a layer of polarized epithelial cells resting on an artificial basement membrane with underlying stromal cells embedded in a collagen matrix resembling the normal endometrium. Using this cell culture system, we have investigated the cellular alterations involving key molecular markers associated with differentiation and implantation to test whether such culture system can be adaptive for in vitro endometrium model. By assessing the expression of integrins, COXs and MMPs as well as the ultrastructural, morphological and functional characteristics of the reconstructed endometrium in comparison with the in vivo counterpart of a mid-luteal phase, this three-dimensional ES and EE cell culture seemed to serve as an useful model for investigatng in vitro implantation mechanism.

\section{Materials and Methods}

\section{Endometrial tissue sampling}

Endometrial tissues were obtained from patients under the age of 40 who underwent a hysterectomy due to conditions other than endometrial disease. After hysterectomy, sampling of uterine fundus was performed using a surgical curette. A part of the endometrial tissue was examined by histological classification (Noyes et al., 1950; Noyes and Haman, 1953) and samples in the late proliferative phase of the menstrual cycle were included in the experiment. All patients gave informed consent and the Ethical Committee of the University approved this study.

\section{Endometrial cell culture}

Tissue samples were transferred to conical tubes with the culture medium consisting of DMEM : F12 and HEPES (Gibco BRL life technologies, Gaitherburg, MD, USA) and washed three times with the same medium to remove residual blood clots. After pouring 2-3 $\mathrm{ml}$ of the culture medium into the culture dish, the tissues were placed into the dish and minced into small pieces with sterile scissors. The tissues were transferred to the conical tube with media and subsequently the supernatant was removed after centrifugation. To the pellet, 5 $\mathrm{ml}$ of trypsin-EDTA solution was added and incubated in a shaker at room temperature for $15 \mathrm{~min}$. To quench the enzymatic reaction, the same amount of the culture medium containing $10 \%$ bovine calf serum (Gibco BRL) was added and then centrifuged. The pellet was resuspended in $10 \mathrm{ml}$ of the culture medium. After washing several times, the cells were allowed to settle at room temperature for $30 \mathrm{~min}$. The upper $7 \mathrm{ml}$ containing the stromal cells and the lower $3 \mathrm{ml}$ containing the epithelial cells were separately inoculated in $60 \mathrm{~mm}$ culture dishes and cultured in the culture medium containing 1 $\%$ penicillin-streptomycin and $10 \%$ bovine calf serum. When necessary, $100 \mathrm{nM}$ progesterone (Sigma, St Louis, $\mathrm{MO}, \mathrm{USA}$ ) and $1 \mathrm{nM}$ estradiol (Sigma) were added to the culture medium.

To prepare for the three-dimensional endometrium model, the lumps of EE cells were collected from the dish by flushing with media. They were transferred to conical tube and 1,000 U/ml of type IV collagenase (Sigma) was added to dissociate the lumps into individual cells. After incubation with shake at room temperature for 15 min, the cells were washed twice with the culture medium containing $10 \%$ bovine calf serum. The ES cells were dislodged from the culture dish by treatment with trypsin-EDTA followed by washing with the culture medium containing serum. The pellet of ES cells was resuspended in the culture medium supplemented with collagen (rat tail type I; Collaborative Biomedical Products, Bedford, MA, USA) to give a final cell density of $1 \times 10^{6} / \mathrm{ml}$ and a collagen concentration of $0.72 \mathrm{mg} / \mathrm{ml}$. Two hundred $\mathrm{ml}$ of the mixture was poured into the 12 $\mathrm{mm}$ cell culture insert (Sigma) and incubated at $37^{\circ} \mathrm{C}$ for $30 \mathrm{~min}$ to solidify the gel. On the top of the solid collagen gel, $50 \mu \mathrm{l}$ of Matrigel (Sigma) at a concentration of $1 \mathrm{mg} / \mathrm{ml}$ was loaded and left to stand for $30 \mathrm{~s}$. After removing the remaining fluid, $200 \mu \mathrm{l}$ of the EE cell suspension at a cell density of $1 \times 10^{6}$ cells $/ \mathrm{ml}$ was inoculated over Matrigel. The cell culture insert was then placed into a 24-well culture dish (Nunc A/S, Roskilde, Denmark) and cultured for $48 \mathrm{~h}$. For the comparison, an endometrium model consisting of only EE cells without ES cells were also prepared and cultured.

\section{Preparation for electron microscopy}

The three-dimensionally cultured endometrial cells were fixed for $3 \mathrm{~h}$ in $3 \%$ glutaraldehyde in $0.1 \mathrm{M}$ Millonig's phosphate buffer $\mathrm{pH}$ 7.3. After washing with the same solution, the samples were post-fixed with $1 \%$ osmium tetroxide in $0.1 \mathrm{M}$ Millonig's phosphate buffer for $80 \mathrm{~min}$, dehydrated serially with ethanol, and placed in propylene oxide.

For transmission electron microscopy (TEM), blocks were made with Epon and thermal polymerization. The flat blocks were sectioned into $1 \mu \mathrm{m}$ slices using an ultramicrotome. The tissue sections were stained with $1 \%$ toluidine blue and examined under a light micro- 
scope. The areas of interest were finely sectioned with an ultramicrotome into 50-70 nm thick slices and attached to a copper grid (200 mesh). The samples were doubly stained with $2 \%$ uranyl acetate and lead citrate and observed under the TEM $(\mathrm{H}-600$, Hitachi, Tokyo, Japan).

For scanning electron microscope (SEM), the samples were dried in a critical point dryer. The samples were attached to the stage and sputtered with $20 \mathrm{~nm}$ of gold. The preparations were examined using the SEM (S$2380 \mathrm{~N}$, Hitachi, Tokyo, Japan) at $25 \mathrm{kV}$.

\section{Immunohistochemistry}

The three-dimensionally cultured samples were fixed in $10 \%$ formalin and embedded in paraffin. The paraffin was sectioned into $5 \mu \mathrm{m}$-thick slices, which were rehydrated and treated with 3\% hydrogen peroxide for $5 \mathrm{~min}$ to remove the remaining endogenous peroxidase activity. The samples were reacted with 1/200 diluents of the antibodies against cytokeratin, integrin subunits $(\alpha 1$, $\alpha 4$ and $\beta 3$ ) (antihuman mouse monoclonal, Santa Cruz Biotechnology Inc.), COX (1 and 2), MMPs (1, 2, 3 and
9), TIMPs (1 and 2) (antihuman goat polyclonal, Santa Cruz Biotechnology Inc.). As a negative control, primary antibodies were omitted during processing. The samples were then reacted with the secondary antibodies included in the LSAB-kit (DAKO A/S, Glostrup, Denmark) for $15 \mathrm{~min}$. After washing with the reaction buffer, samples were stained with diaminobenzidine (DAKO A/S) for 5 min followed by counter staining with hematoxylin for 10 s. The samples were sealed with Canadian balsam and were observed under a light microscope.

\section{Gelatin substrate zymography}

The supernatant of the culture media was mixed with the same amount of zymographic sample buffer $(10 \%$ SDS, $4 \%$ sucrose, $0.25 \mathrm{M}$ Tris- $\mathrm{HCl}, \mathrm{pH} 6.8,0.1 \%$ bromophenol blue). Ten $\mu$ l of each sample was separated on $9 \%$ polyacrylamide gel containing $0.1 \%$ gelatin. The gels were washed twice with the detergent solution (Tris- $\mathrm{HCl}, \mathrm{pH} 8.0,2.5 \%$ Triton $\mathrm{X}-100$ ) and incubated in the substrate buffer $(50 \mathrm{mM}$ Tris- $\mathrm{HCl}, \mathrm{pH} 8.0,5 \mathrm{mM}$ $\mathrm{CaCl}_{2}, 0.02 \% \mathrm{NaN}_{3}$ ) at $37^{\circ} \mathrm{C}$ for $24 \mathrm{~h}$. Then the gels were subsequently treated with a staining solution $(0.5 \%$
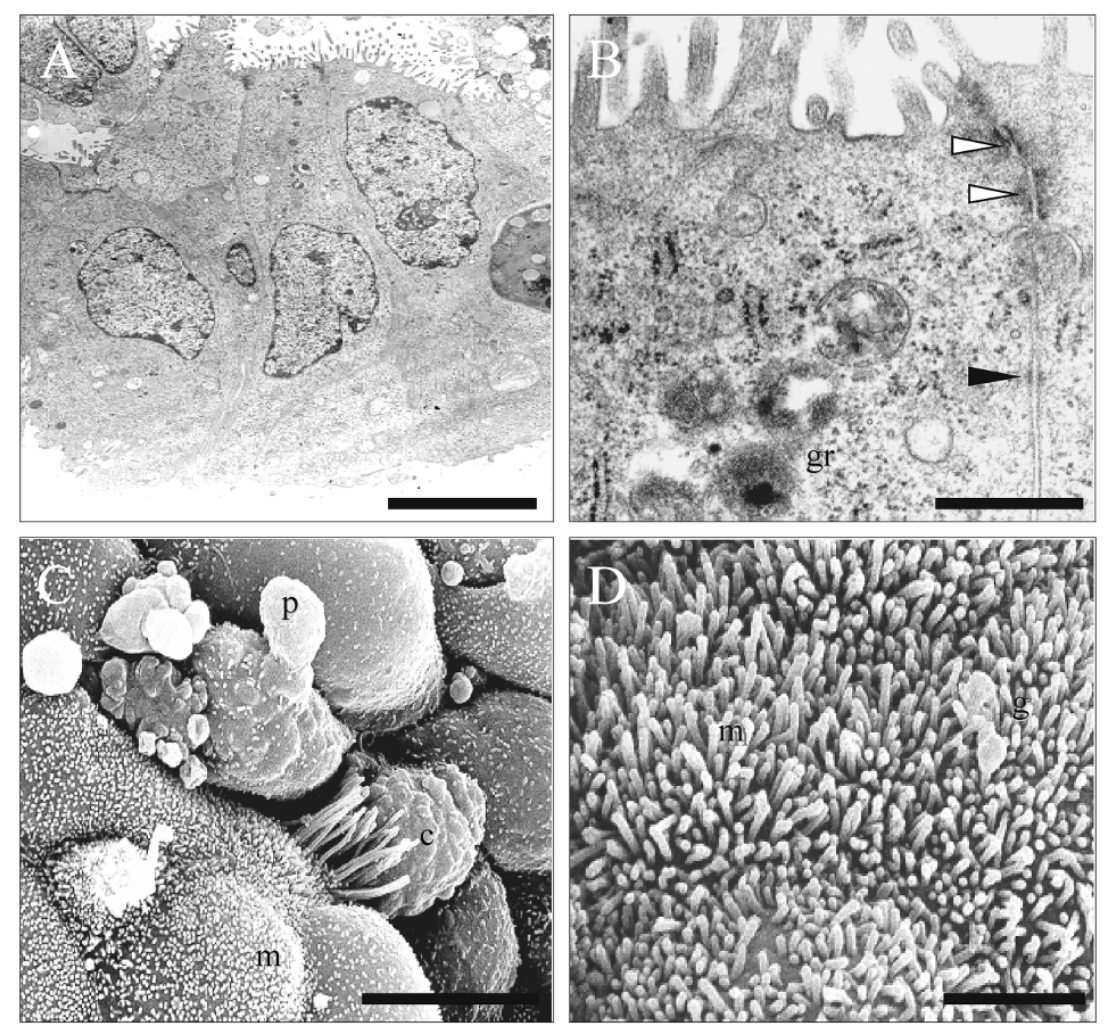

Figure 1. Electron microphotographs of three-dimensionally cultured endometrial cells. The transmission electron microscopy images of three-dimensionally cultured EE cells (A, B). Left panel: The cultured EE cells were polarized to columnar cells with basely located nuclei and mitochondria. Right panel: The granules (gr) were located in a row between the nucleus and the apical membrane of an EE cell. The junctions of the epithelial cells were comprised of apical tight junctions (open arrowheads) and rivet-like desmosomes (close arrowhead). The scanning electron microscopy images of three-dimensionally cultured epithelial cells $(C, D)$. Left panel: Some epithelial cells had a pinopodes $(p)$ protruding. The surface of the epithelial cells was abundantly covered with microvilli (m) and some cells were ciliated (c). Right panel: Some cells showed granule-like protrusions (g). Scale bars represent $5 \mu \mathrm{m}(\mathrm{A}), 1 \mu \mathrm{m}(\mathrm{B}), 10 \mu \mathrm{m}(\mathrm{C})$ and $2 \mu \mathrm{m}(\mathrm{D})$, respectively. 
Coomassie brilliant blue R-250, 10\% acetic acid, 30\% isopropyl alcohol) at room temperature for $1 \mathrm{~h}$, and destained with distilled water at room temperature for $5 \mathrm{~h}$.

\section{Results}

When ES cells were cultured in collagen matrix, the structure of the collagen matrix was maintained regardless of the presence of progesterone and estradiol although minimal contraction of the structure was observed in some samples. In contrast, the reconstructed endometrium culture consisting of both ES and EE cells collapsed within $12 \mathrm{~h}$. However, in the presence of progesterone and estradiol, the entire structure of the three-dimensionally co-cultured ES and EE cells model had sustained up to 48-72 $\mathrm{h}$ after which it progressively contracted and then dissolved (data not shown).

When the endometrium reconstructed with both ES and EE cells cultured in the presence of progesterone and estradiol was examined under light microscope, monolayered columnar EE cells covered the surface of Matrigel and ES cells embedded in collagen matrix localized under the EE cells. TEM revealed that columnar EE cells were polarized and exhibited the presence of microvilli on the surface and of nuclei and mitochondria located at the lower part. The cytoplasmic granules in the EE cell were located in a row between the nucleus and the apical membrane of the epithelial cell. The junctions between EE cells were comprised of apical tight junctions and rivet-like desmosomes (Figure $1 \mathrm{~A}, \mathrm{~B})$. The surface of the three-dimensionally cultured endometrium observed by SEM was completely covered by the EE cells. The apical surface of the EE cells was covered abundantly with microvilli and some of them protruded as pinopodes (Figure 1C, D).

Intense immunoreactivity against anti-cytokeratin antibody was identified only in the EE cells of the reconstructed endometrium model cultured with the steroid hormones (Figure 2A). Integrin subunits of $\alpha 1, \alpha 4$ and $\beta 3$ were strongly expressed in the EE cells and in part of the ES cells (Figure 2C, E, G). COX-1 and -2 were also strongly stained in both the EE cells and some of the ES cells (Figure 2l, K). The endometrium obtained from human uterus at mid secretory phase as an in vivo counterpart also showed similar immunoreactivity of the reconstructed endometrium model (Figure 2D, F, H, J, L). In monolayer cultures, EE cells showed a distinct reactivity with anti-cytokeratin antibody but failed to react with antibodies against integrin $\alpha 1, \alpha 4$ and $\beta 3$, whereas monolayer-cultured ES cells did not react with any of these antibodies (Figure $3 \mathrm{~A}-\mathrm{H}$ ). However, both EE and ES cells were stained with anti-COX-1 and -2 antibodies (Figure 3I-L). In the reconstructed endometrium model, both EE and ES cells showed a strong reactivity with all of the antibodies against MMP-1, -2, -3, -9, and

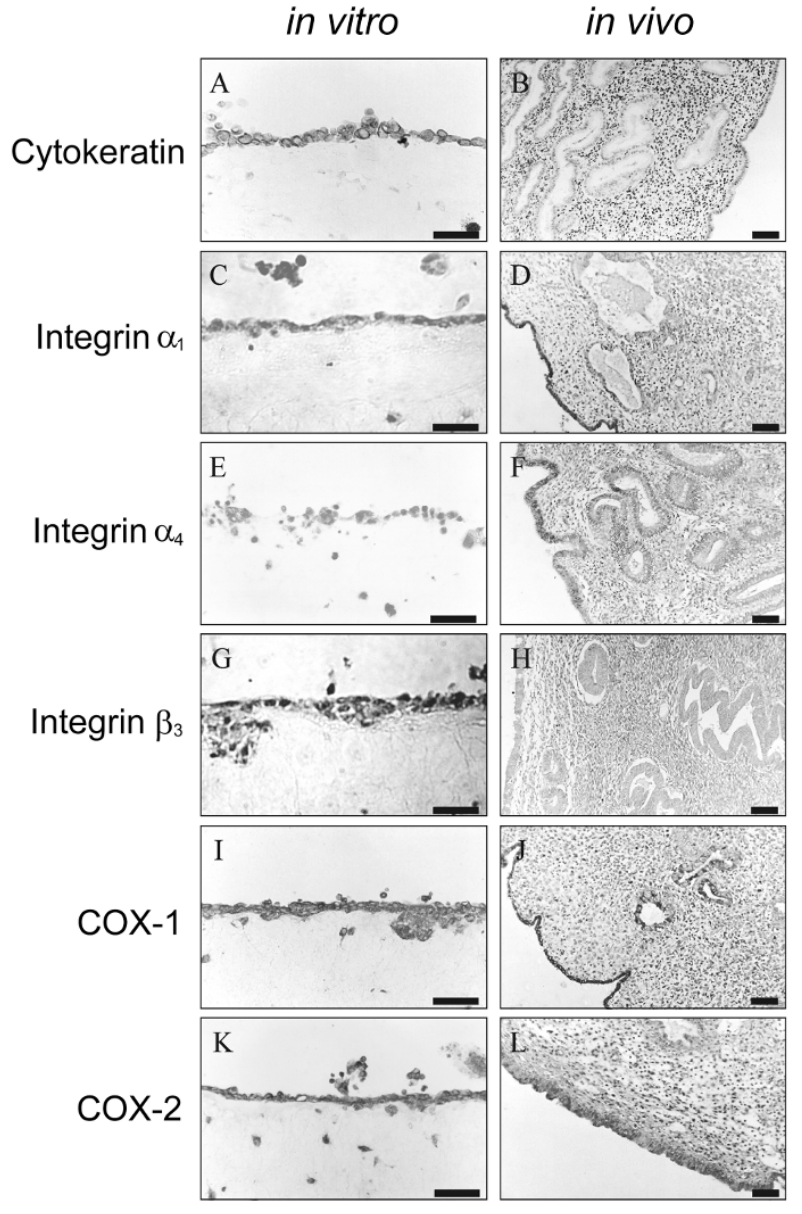

Figure 2. Light microphotographs of epithelial and stromal cells stained with antibodies against integrins and COX-1 and -2 in the three-dimensional endometrial cell culture system under sex steroid hormone control. Positive staining of cytokeratin in the monolayered cells on the top of threedimension cultures confirmed the epithelial origin of these cells (A). Positive staining of integrin $\alpha 1(C), \alpha 4(E)$ and $\beta 3(G)$ was demonstrated at the epithelial cells. Both epithelial and stromal cells showed positive staining of COX-1 (I) and -2 (K). Human endometrium at mid secretory phase was also stained with same antibodies for integrin $\alpha 1, \alpha 4, \beta 3, \mathrm{COX}-1$ and COX-2 (D, $\mathrm{F}, \mathrm{H}, \mathrm{J}, \mathrm{L}$, respectively). Positive staining of progesterone receptor was shown in human endometrium as control (B). Scale bars represent $50 \mu \mathrm{m}$.

TIMP-1 and -2 (Figure 4A, C, E, G, I, K). In contrast, ES cells embedded alone in the collagen matrix was not stained with anti-MMP antibodies, although some of ES cells showed a positive immunoreactivity with antiTIMP-1 and -2 antibodies (Figure 4B, D, F, H, J, L).

Gelatin substrate zymography of the culture media collected from the reconstructed endometrium model system consistently showed that intense bands appeared at 72, 60 and $57 \mathrm{kDa}$ and weak bands at 97, 92 and $84 \mathrm{kDa}$ when estradiol and progesterone were not added to the culture. However, the culture media obtained from the model treated with both estrogen and progesterone showed an increased activity of 97, 92 and $84 \mathrm{kDa}$ gelatinases and concomitantly a reduced 


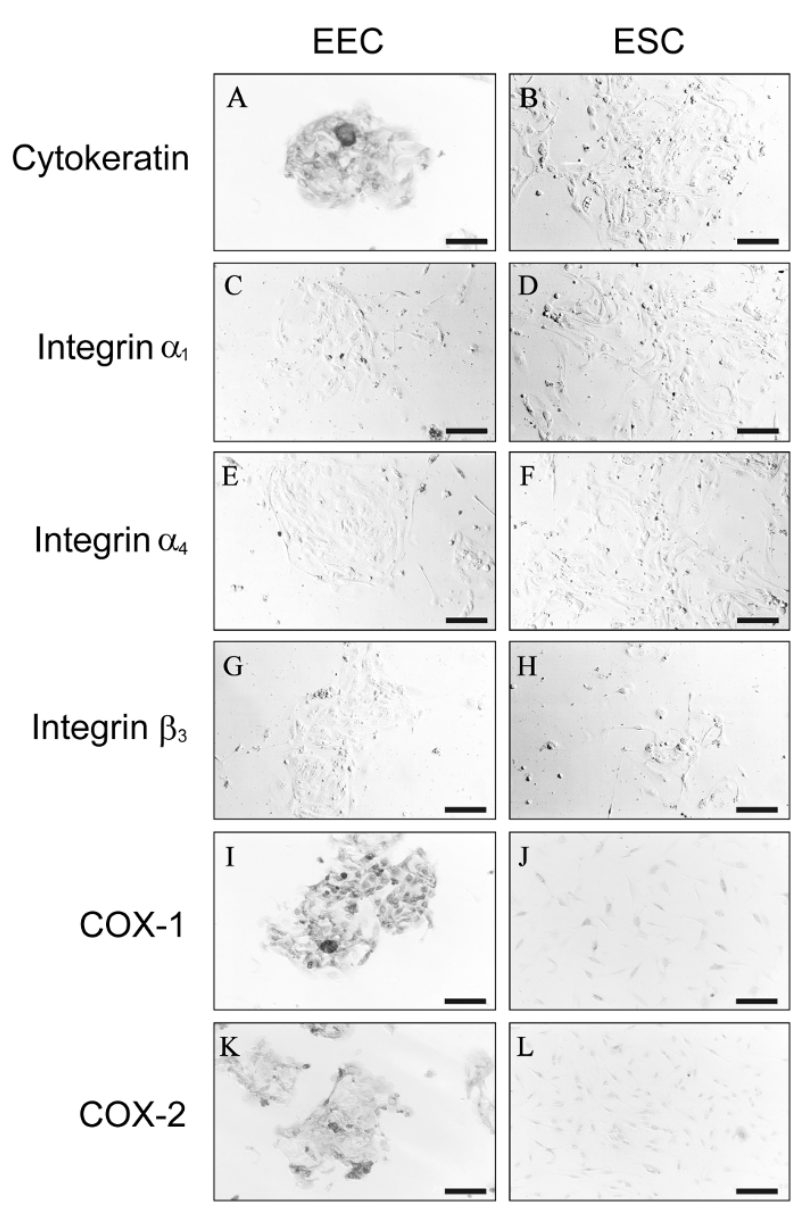

Figure 3. Light microphotographs of primarily cultured cells stained with antibodies against cytokeratin, integrins and COX-1 and -2. Left column: epithelial cells, right column: stromal cells. Positive staining of cytokeratin was noted in the epithelial origin of these cells but not in stromal $(A, B)$. Expression of integrin $\alpha 1, \alpha 4$ and $\beta 3$ was not detected in both monolayered epithelial and stromal cells $(\mathrm{C}-\mathrm{H})$. The epithelial and stromal cells showed strong and mild expression of COX-1 and 2, respectively (I-L). Scale bars represent $100 \mu \mathrm{m}$.

activity of 72 and $60 \mathrm{kDa}$ gelatinases (Figure $5 \mathrm{~A}$ ). In the media from the culture of ES cells alone embedded in collagen matrix, however, very weak activity of 84,60 and $57 \mathrm{kDa}$ gelatinases was detected regardless of the presence of sex steroid hormones (Figure 5B).

\section{Discussion}

The human endometrium is composed of the epithelium, stroma and collagen-rich extracellular matrix. The proliferation and differentiation of these cells and extracellular components are achieved under the cyclic influence of sex steroids (Edwards, 1995). However, the paracrine interaction among the EE and ES cells and ECM plays an important role in the process of proliferation and differentiation (Wegner and Carson, 1992; Klentzeris, 1997). In a study using a separate culture of

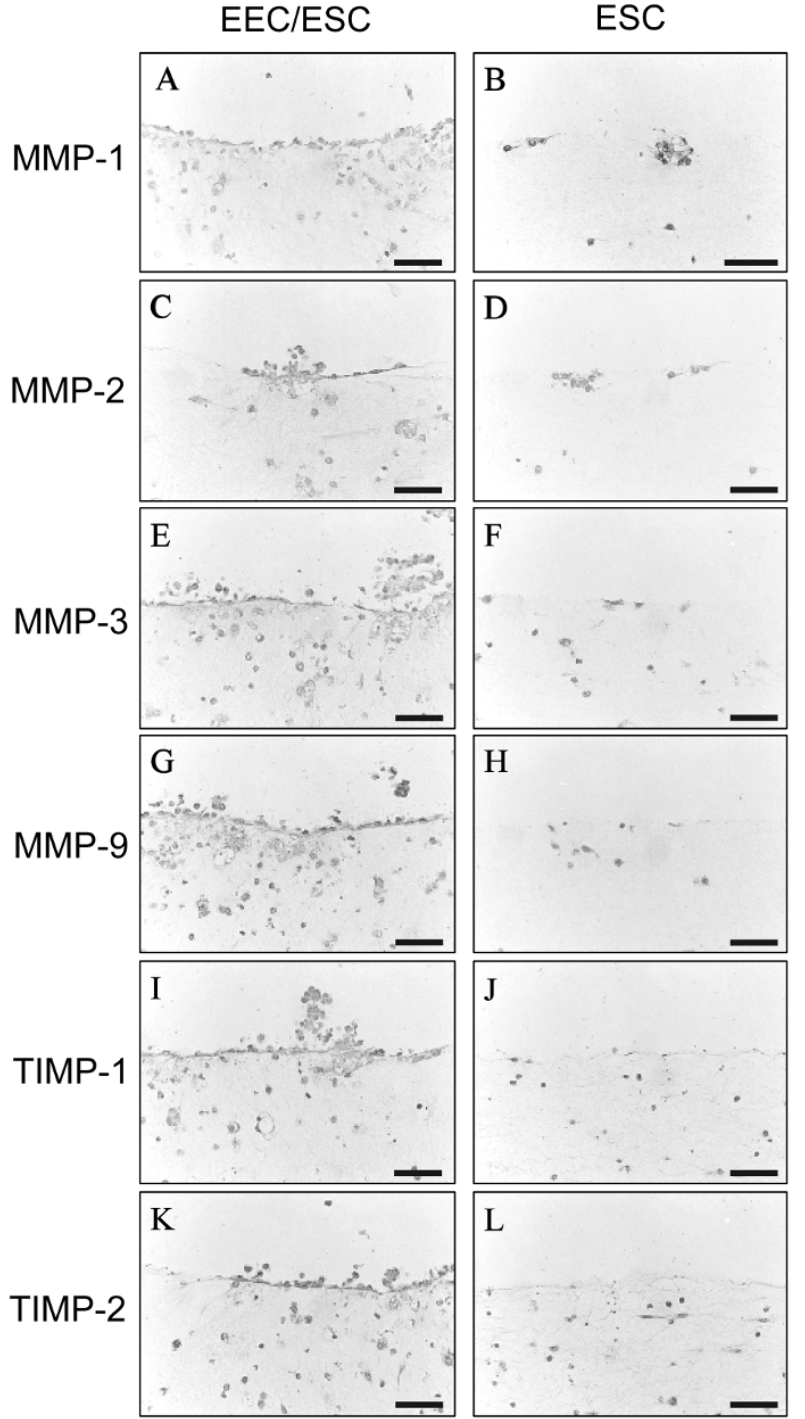

Figure 4. Light microphotographs of epithelial and stromal cells stained with antibodies against MMPs and TIMPs in the three-dimensional endometrial cell culture system under sex steroid hormone control. The three dimensionally co-cultured epithelial and stromal cells all showed strong MMP-1, $-2,-3$ and -9 expression (A, C, E, G). TIMP-1 and -2 are expressed in both the co-cultured epithelial and stromal cells $(\mathrm{I}, \mathrm{K})$. Three-dimensional culture of stromal cells only in a collagen gel showed no MMP-1, $-2,-3$ and -9 expression (B, D, F, H). TIMP-1 and -2 were expressed in the cultures of stromal cells only $(\mathrm{J}, \mathrm{K})$. Scale bars represent $50 \mu \mathrm{m}$.

murine EE and ES cells, it was shown that soluble proteins from the conditioned culture medium of EE cells could regulate the function of the stromal cells by inducing the synthesis of $30 \mathrm{kDa}$ protein (Wegner and Carson, 1992). Similarly when the conditioned culture medium of human EE cells was added to the endometrial fibroblast cell culture, MMP-1 expression in endometrial fibroblasts was markedly stimulated by interleukin$1 \alpha$ secreted from the epithelial cells (Singer et al., 1997). These results suggest that the paracrine action between the endometrial components is responsible for 


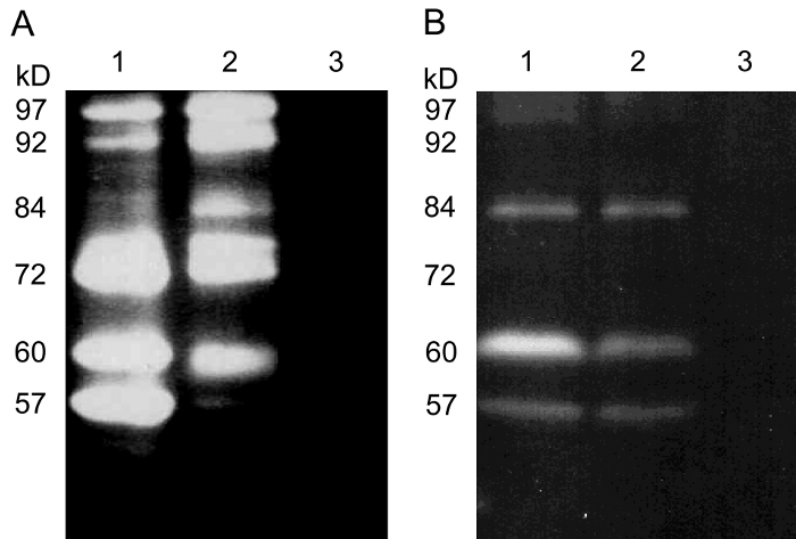

Figure 5. Representative gelatin zymogram of the media from the threedimensional endometrium model and the only -ES cells-culture in the collagen gel. A. The media from three-dimensionally co-cultured EE and ES cells displayed high 97, $92 \mathrm{kDa}$ gelatinase activity and minor 84,72 and 60 $\mathrm{kDa}$ gelatinase activities after treatment with both estradiol $\left(\mathrm{E}_{2}\right)$ and progesterone $\left(\mathrm{P}_{4}\right)$. When estrogen and progesterone were not added to the culture, clear bands at 72, 60 and $57 \mathrm{kDa}$ and minor bands at $97,92 \mathrm{kDa}$ appeared. (Lane 1: $E E$ and $E S$ cells without $E_{2}+P_{4}$, Lane 2: $E E$ and $E S$ cells with $E_{2}+P_{4}$, Lane 3: only medium for negative control) $B$. The media from the culture of only ES cells in the collagen gel showed very low gelatinase activity regardless of the presence of hormone. (Lane 1: ES cells without $E_{2}+P_{4}$, Lane 2: $E S$ cells with $E_{2}+P_{4}$, Lane 3: only medium for negative control).

the differentiation and functional regulation of the endometrium.

The reconstructed three-dimensional model consisting of both EE and ES cells in this study demonstrated structural and functional similarities of the in vitro endometrium to the in vivo counterpart. The appearance of numerous microvilli, cilia and pinopodes on the apical surface of the EE cells showed that the EE cells of the three-dimensional model could maintain its intact structure like the endometrium in vivo (Martel et al., 1987; Bentin-Ley et al., 1999; Nikas et al., 1999). This is further supported by the presence of tight junctions and desmosomes in the lateral junctional complex between EE cells (Bentin-Ley et al., 1994).

Among the many implantation-related molecules, the most extensively studied ones are integrins. In human, the mid-luteal phase EE cells are characterized by the expression of $\alpha 1, \alpha 4$, and $\beta 3$ subunits of integrin (Lessey et al., 1994). The EE cells in our reconstructed endometrium also exhibited the expression of the same integrin subunits. However, neither ES nor EE cells expressed the integrins when they were cultured separately in a monolayer. Sillem et al. (1997) reported that the endometrial cell cultured in vitro expressed the subunits of $\alpha_{1} \beta_{1}, \alpha_{2} \beta_{1}, \alpha_{4} \beta_{1}, \alpha_{5} \beta_{1}, \alpha_{v} \beta_{3}$, and $\beta_{1}$ integrins and the expression was not affected by the steroid hormones. But Simon et al. (1997) showed that EE cells cultured in vitro expressed only $\beta 3$ subunits of integrin but not $\alpha 1$ and $\alpha 4$ subunits. Such discrepancy could be due to the variation of tissues obtained at different endometrial phases. Alternatively, EE cells cultured in the absence of stromal layer might not function properly, resulting in the inconsistent expression of integrin molecules. It has been reported that $\beta 3$ subunit of integrin expression is up-regulated in endometrial cells when they are co-cultured with blastocysts (Simon et al. 1996). These results collectively suggest that both sex steroid hormones and paracrine interaction between the EE, ES cells and blastocysts are important regulators for integrin expression in the human luteal phase EE cells.

Endometrial COX-2 is known to induce the angiogenesis via regulating the expression of VEGF, PDGF and TGF- $\beta$ (Malathy et al., 1986). A targeted disruption of COX-2 in mice has been reported to produce multiple failures of the female reproductive process that includes ovulation, fertilization, implantation, and decidualization (Lim et al., 1997). In human, COX-1 protein expression in uterine luminal epithelial cells is consistently high throughout the menstrual cycle. In contrast, expression of the COX-2 protein is relatively low during the proliferative phase and reaches a peak in the mid-luteal phase in both the EE and ES cells (Kwon et al., 1999). High prostaglandin production enhanced by COX-2 in the mid-luteal endometrium is related to the increased vascular permeability and decidualization (Jacobs and Carson, 1993). We have observed that COX-1 and 2 proteins were expressed not only in three-dimensionally cultured EE and ES cells but also in those cultured in a monolayer, suggesting that expression of COX proteins may not be regulated by the paracrine interaction between EE and ES cells.

Remodeling of endometrial tissue during the menstrual cycle is the result of changes in the extracellular matrix, which is degraded by various MMPs (Rudolph-Owen et al., 1998). The expression of MMP subtypes varies during the menstrual cycle and is intimately related to the process of ovulation and implantation (Hulboy et al., 1997). Progesterone withdrawal facilitates MMP production by the endometrial cells both in vivo and in vitro. This finding provides another explanation for endometrial tissue shedding in the menstrual phase (Marbaix et al., 1996; Salamonsen et al., 1997; Lockwood et al., 1998). However, little is known about the relation between expression of MMPs and progesterone. In addition, the expression of the tissue inhibitor of metalloproteinases (TIMPs) was known to be independent of the action of progesterone (Salamonsen et al., 1997). In the present zymographic experiment, the gelatinolytic profiles of MMPs secreted from the reconstructed endometrium cultured in the presence of progesterone differed markedly from that of MMPs secreted from the same endometrium cultured in the absence of progesterone. In the threedimensional endometrium model, the gelatinolytic activity was very strong and depends on the sex steroid hormones. The hormones suppressed the activities of gelatinases except $92 \mathrm{kDa}$ and $97 \mathrm{kDa}$ gelatinases. The 
activity of $92 \mathrm{kDa}$ gelatinase, which was regarded as MMP-9 by molecular weight, was higher after the addition of the sex steroid hormones. This finding paralleled with the observation that progesterone increased MMP9 expression in decidualized stromal cells (Skinner et al., 1999). In contrast, the gelatinolytic activity of the ES cells alone cultured in the collagen gel was very weak regardless of the presence of sex steroid hormones. These results confirmed that the modulation of MMP activity is dependent on the interaction between the EE and ES cells (Osteen et al., 1994; Singer et al., 1997; Lockwood et al., 1998).

The present study suggests that the sex steroid hormone-dependent differentiation of the endometrium is controlled largely by interactions between the EE and ES cells. It provides further evidences that our threedimensionally cultured endometrium model could mimic the morphological and functional characteristics of the endometrium in vivo. The model could be used to clarify the roles of various molecules involved in the human implantation.

\section{Acknowledgement}

This work has been previously presented at the 2001 annual meeting of Korean Society of Medical Biochemistry and Molecular Biology. This study was supported by a grant of the Korea Health 21 R\&D Project, Ministry of Health \& Welfare, Republic of Korea. (01-PJ10-PG601GN13-0002).

\section{References}

Acosta AA, Elberger L, Borghi M, Calamera JC, Chemes $H$, Doncel GF, Kliman H, Lema B, Lustig L, Papier S. Endometrial dating and determination of the window of implantation in healthy fertile women. Fertil Steril 2000;73:788-98

Bentin-Ley U, Pedersen B, Lindenberg S, Larsen JF, Hamberger $\mathrm{L}$, Horn $\mathrm{T}$. Isolation and culture of human endometrial cells in a three-dimensional culture system. J Reprod Fertil 1994; 101:327-32

Bentin-Ley U, Sjogren A, Nilsson L, Hamberger L, Larsen JF, Horn T. Presence of uterine pinopodes at the embryo-endometrial interface during human implantation. Hum Reprod 1999;14:515-20

Charnock-Jones DS, Sharkey AM, Fenwick P, Smith SK. Leukemia inhibitory factor mRNA concentration peaks in human endometrium at the time of implantation and the blastocyst contains mRNA for the receptor at this time. $J$ Reprod Fertil 1994;101:421-26

Edwards RG. Physiological and molecular aspects of human implantation. Hum Reprod 1995;10 (Suppl. 2): 1-13

Fowle DJ, Nicolaides KH, Miell JP. Insulin-like growth factor binding protein-1 (IGFBP-1): a multifunctional role in the human female reproductive tract. Hum Reprod Update 2000; 6:495-504

Guidice LC. Growth factors and growth modulators in human uterine endometrium: their potential relevance to reproductive medicine. Fertil Steril 1994;61:1-17

Hearn JP. The embryo-maternal dialogue during early pregnancy in primates. J Reprod Fertil 1986;76:809-19

Hulboy DL, Martrisian LM. Matrix metalloproteinases as mediators of reproductive function. Mol Hum Reprod 1997;3:27-45

Jacobs AL, Carson DD. Uterine epithelial cell secretion of interleukin-1induces prostaglandin E2 (PGE2) and PGF2 $\alpha$ secretion by uterine stromal cells in vitro. Endocrinology. 1993;132:300-8

Jones RL, Kelly RW, Critchley HO. Chemokine and cyclooxygenase-2 expression in human endometrium coincides with leukocyte accumulation. Hum Reprod 1997;12:1300-6

Klentzeris LD. The role of endometrium in implantation. Hum Reprod 1997;12(Suppl. 11):170-75

Kwon HC, Yang HW, Hwang KJ, Kim SK, Cho DJ, Oh KS. Pattern of cyclooxygenase expression in the human endometrium during the menstrual cycle. Presented at the $15^{\text {th }}$ Annual meeting of the European Society of Human Reproduction and Embryology, Tours, France. Hum Reprod 1999;14(Abstract Bk. 1):270-71

Lessey BA, Castelbaum AJ, Buck CA, Lei Y, Yowell CW, Sun $J$. Further characterization of endometrial integrins during the menstrual cycle and in pregnancy. Fertil Steril;62:497-506

Lim H, Paria BC, Das SK, Dinchuk JE, Langenbach R, Trzaskos JM, Dey SK. Multiple female reproductive failures in cyclooxygenase 2-deficient mice. Cell 1997;91:197-208

Lockwood CJ, Krikun G, Hausknecht VA, Papp C, Schatz F. Matrix metalloproteinase and matrix metalloproteinase inhibitor expression in endometrial stromal cells during progestininitiated decidualization and menstruation-related progestin withdrawal. Endocrinology 1998;139:4607-13

Malathy PV, Cheng HC, Dey SK. Production of leukotrienes and prostaglandins in the rat uterus during peri-implantation period. Prostaglandins 1986;32:605-14

Marbaix E, Kokorine I, Moulin P, Donnez J, Eeckhout Y, Courtoy PJ. Menstrual breakdown of human endometrium can be mimicked in vitro and is selectively and reversibly blocked by inhibitors of matrix metalloproteinases. Proc Natl Acad Sci USA 1996;93:9120-25

Martel D, Frydman R, Glissant M, Maggioni C, Roche D, Psychoyos A. Scanning electron microscopy of postovulatory human endometrium in spontaneous cycles and cycles stimulated by hormone treatment. J Endocrinol 1987;114:31924

Nikas G, Develioglu OH, Toner JP, Jones HW Jr. Endometrial pinopodes indicate a shift in the window of receptivity in IVF cycles. Hum Reprod 1999;14:787-92

Noyes RW, Haman JO. Accuracy of endometrial dating. Correlation of endometrial dating with basal temperature and menses. Fertil Steril 1953;4:504-17 
Noyes RW, Hertig AT, Rock J. Dating the endometrial biopsy. Fertil Steril 1950;1:3-25

Osteen KG, Rodgers WH, Gaire M, Hargrove JT, Gorstein F, Matrisian LM. Stromal-epithelial interaction mediates steroidal regulation of metalloproteinase expression in human endometrium. Proc Natl Acad Sci USA 1994;91:10129-33

Rudolph-Owen LA, Slayden OD, Matrisian LM, Brenner RM. Matrix metalloproteinase expression in Macaca mulatta endometrium: evidence for zone-specific regulatory tissue gradients. Biol Reprod 1998;59:1349-59

Salamonsen LA, Butt AR, Hammond FR, Garcia S, Zhang J. Production of endometrial matrix metalloproteinases, but not their tissue inhibitors, is modulated by progesterone withdrawal in an in vitro model for menstruation. J. Clin. Endocrinol. Metab. 1997;82:1409-15

Salamonsen LA, Zhang J, Hampton A, Lathbury L. Regulation of matrix metalloproteinases in human endometrium. Hum Reprod 2000;15(Suppl. 3): 112-19

Sillem M, Prifti S, Schmidt M, Rabe T, Runnebaum B. Endometrial integrin expression is independent of estrogen or progestin treatment in vitro. Fertil Steril 1997;67:877-82

Simon C, Gimeno MJ, Mercader A, Frances A, Garcia Velasco J, Remohi J, Polan ML, Pellicer A. Cytokines-adhe- sion molecules-invasive proteinases. The missing paracrine/ autocrine link in embryonic implantation? Mol Hum Reprod 1996;2:405-24

Simon C, Gimeno MJ, Mercader A, O'Connor JE, Remohi J, Polan ML, Pellicer A. Embryonic regulation of integrins beta 3, alpha 4, and alpha 1 in human endometrial epithelial cells in vitro. J Clin Endocrinol Metab 1997;82:2607-16

Singer CF, Marbaix E, Kokorine I, Lemoine P, Donnez J, Eeckhout Y, Courtoy PJ. Paracrine stimulation of interstitial collagenase (MMP-1) in the human endometrium by interleukin 1alpha and its dual block by ovarian steroids. Proc Natl Acad Sci USA 1997;94:10341-45

Skinner JL, Riley SC, Gebbie AE, Glasier AF, Critchley HO. Regulation of matrix metalloproteinase-9 in endometrium during the menstrual cycle and following administration of intrauterine levonorgestrel. Hum Reprod 1999;14:793-99

Tabibzadeh S, Sun XZ. Cytokine expression in human endometrium throughout the menstrual cycle. Hum Reprod 1992;7:1214-21

Wegner CC, Carson DD. Mouse uterine stromal cells secrete a 30 kilodalton protein in response to coculture with uterine epithelial cells. Endocrinology 1992;131:2565-72 